\title{
HUBUNGAN ANTARA KEPUASAN SISWA DAN PERSEPSI KINERJA GURU PROFESIONAL DENGAN HASIL BELAJAR SISWA PADA MATA PELAJARAN PEKERJAAN DASAR ELEKTROMEKANIK
}

${ }^{1}$ Siti Mardiah, ${ }^{2}$ Soeprijanto, ${ }^{3}$ Faried Wadjdi

1,2,3 Pendidikan Teknik ElektroTeknik Elektro, Universitas Negeri Jakarta

Email : dicmadiah21@gmail.com

\begin{abstract}
This research aims to determine the relationship between student satisfaction and perception of professional teacher performance with student learning outcomes electromechanical basic work subjects. This research was conducted in 5 Vocational High School of Jakarta. The method used is the method of survey. Collecting data using techniques of observation and questionnaires. Affordable population in this study were students of the X grade electrical engineering student totaling 90 students and the sample research taken as many as 40 students.

The test results by using a correlation coefficient of pearson product moment obtained value $r_{x y} X_{1} 0.920 \mathrm{r}_{\mathrm{xy}}$ $\mathrm{X}_{2}$ 0,940 dan $\mathrm{R}$ 0,722. This means that together there is a positive relationship between student satisfaction about professional teacher performance with student learning outcomes electromechanical basic work subjects. From t-test calculations obtained $X_{1} t_{\text {count }}>t_{\text {table }}(14,52>2,02)$, which showed a significant relation between the variable $X_{1}$ is student satisfaction about professional teacher performance with variable $Y$ is Student Learning Outcomes Electromechanical basic work Subject and for variable $X_{2}$ obtained $t_{\text {count }}>t_{\text {table }}$ $(17,05>2,02)$, which showed a significant relation between the variable $X_{1}$ is professional teacher performance with variable $Y$ is Student Learning Outcomes Electromechanical basic work Subject. From the calculation result obtained coefficient of determination $X_{1} 37.25 \%$ so that it can be said that the variable $Y$ Student Learning Outcomes Electromechanical basic work Subject determined by variable $X_{1}$ student satisfaction about professional teacher performance by 84,73\% And coefficient of determination $X_{2} 88,44 \%$ so that it can be said that the variable $Y$ Student Learning Outcomes Electromechanical basic work Subject determined by variable $X_{2}$ professional teacher performance by $88,44 \%$. To improve students' satisfaction in the future, it is expected that teachers can use more appropriate and suitable learning method with the students and to improve teacher performance expected school always monitor teacher performance every year.
\end{abstract}

Key Word : Student satisfaction, professional teacher performance, learning outcomes

\begin{abstract}
Abstrak
Penelitian ini bertujuan untuk mengetahui hubungan antara kepuasan siswa dan persepsi kinerja guru profesional dengan hasil belajar siswa mata pelajaran pekerjaan dasar elektromekanik. Penelitian ini dilakukan di SMK N 5 Jakarta. Metode yang digunakan adalah metode survei. Pengumpulan data menggunakan teknik pengamatan dan kuesioner. Populasi dalam penelitian ini adalah siswa kelas X TIPTL yang berjumlah 90 siswa dan sampel penelitian diambil sejumlah 40 siswa dengan cara stratified random sampling. Data yang telah terkumpul akan dioleh dengan uji hipotesis setelah data memenuhi persyaratan normalitas, keberartian dan linieritas.

Hasil penelitian menggunakan uji koefisien korelasi dengan menggunakan product moment dari Pearson diperoleh nilai $\mathrm{r}_{\mathrm{xy}} \mathrm{X}_{1} 0,920, \mathrm{r}_{\mathrm{xy}} \mathrm{X}_{2}$ 0,940 dan $\mathrm{R}$ 0,722. Hal ini berarti secara bersama-sama terdapat hubungan yang positif antara kepuasan siswa tentang kinerja guru profesional dan kinerja guru profesional dengan hasil belajar siswa pekerjaan dasar elektromekanik. Dari perhitungan uji-t didapat $X_{1} t_{\text {hitung }}>t_{\text {tabel }}(14,52>2,02)$, yang menunjukkan adanya hubungan yang signifikan antara variabel $\mathrm{X}_{1}$ yaitu kepuasan siswa tentang kinerja guru profesional dengan variabel $\mathrm{Y}$ yaitu hasil belajar pekerjaan dasar elektromekanik dan untuk $\mathrm{X}_{2}$ didapat $\mathrm{t}_{\text {hitung }}>\mathrm{t}_{\text {tabel }}(17,05>2,02)$, yang menunjukkan adanya hubungan yang signifikan antara variabel $\mathrm{X}_{2}$ yaitu kinerja guru profesional dengan variabel Y yaitu hasil belajar pekerjaan dasar elektromekanik. Dari hasil perhitungan diperoleh koefisien determinasi $\mathrm{X}_{1} 84,73 \%$, sehingga dapat dikatakan bahwa variabel $\mathrm{Y}$ hasil belajar pekerjaan dasar elektromekanik ditentukan oleh variabel $\mathrm{X}_{1}$ kepuasan siswa tentang kinerja guru profesional sebesar $84,73 \%$ dan koefisien determinasi $\mathrm{X}_{2} 88,44 \%$, sehingga dapat dikatakan bahwa variabel Y hasil belajar pekerjaan dasar elektromekanik ditentukan oleh variabel $\mathrm{X}_{2}$ kinerja guru profesional sebesar $88,44 \%$.
\end{abstract}

Kata kunci : Kepuasan siswa, kinerja guru profesional, hasil belajar

\section{PENDAHULUAN}

Kegiatan belajar mengajar merupakan salah satu proses pembelajaran dan suatu gabungan, yaitu belajar yang dilakukan oleh siswa dan mengajar yang dilakukan oleh guru sebagai pengajar. Setelah melalui proses belajar mengajar, diperlukan adanya penilaian untuk mengetahui sejauh mana siswa telah menguasai 
pelajaran yang telah diterimanya. Keberhasilan proses belajar mengajar pada siswa dapat dilihat dari hasil belajar siswa tersebut. Dalam mencapai hasil belajar yang baik, terdapat faktor-faktor yang mempengaruhi, yaitu faktor internal dan faktor eksternal. Salah satu faktor eksternal yang mempengaruhi hasil belajar adalah guru. Seorang guru dikatakan profesional apabila dapat bekerja dengan kualitas tinggi dikarenakan pekerjaan guru termasuk dalam bidang jasa atau pelayanan (service) sehingga pelayanan yang berkualitas dari seorang guru ditunjukkan melalui kepuasan dari para pengguna jasa guru yaitu siswa. Kepuasan siswa adalah suatu sikap yang diperlihatkan oleh siswa, baik sikap positif maupun sikap negatif atas adanya kesesuaian harapan siswa terhadap proses belajar yang diberikan oleh guru. Namun permasalahnnya, menjamurnya sekolah-sekolah yang rendah mutunya memberikan suatu isyarat bahwa guru profesional hanyalah sebuah wacana yang belum terealisasi. SMKN 5 Jakarta adalah salah satu sekolah kejuruan yang berada di Jakarta. Paket keahlian yang ada di sekolah tersebut terdiri dari Teknik Instalasi Pemanfaatan Tenaga Listrik, Teknik Audio Video, Teknik Pemesinan dan Teknik Kendaraan Ringan. Dalam paket keahlian Teknik Instalasi Pemanfaatan Tenaga Listrik, daftar mata pelajaran kejuruan untuk kelas X adalah, Gambar Teknik, Pekerjaan Dasar Elektromekanik dan Dasar dan Pengukuran Listrik. Maka dari itu peneliti hendak meneliti apakah terdapat hubungan yang positif dan signifikan antara kepuasan siswa dan kinerja guru profesional dengan hasil belajar siswa mata pelajaran Pekerjaan Dasar Elektromekanik di SMKN 5 Jakarta.

\section{METODE}

Metode penelitian yang digunakan untuk mengetahui hubungan anatar kepuasan siswa tentang kinerja guru profesional dan kinerja guru profesional dengan hasil belajar siswa pada mata pelajaran pekerjaan dasar elektromekanik adalah metode survei

Populasi dalam penelitian ini adalah siswa kelas X jurusan instalasi tenaga listrik SMK N 5 Jakarta yang berjumlah 90 siswa. Sementara sampel dalam penelitian ini diambil menggunakan Stratified Random Sampling, sehingga sampel dalam penelitian ini berjumlah 40 siswa.

Dalam penelitian ini menggunakan kuisioner untuk variabel bebas, yaitu kepuasan siswa tentang kinerja guru profesional $\left(\mathrm{X}_{1}\right)$ dan kinerja guru profesional $\left(\mathrm{X}_{2}\right)$ dan untuk variabel terikat hasil belajar siswa (Y) didapatkan dari nilai raport siswa.

Setelah semua data diperoleh, maka dilakukan uji prasayat analisis data, yaitu melalui perhitungan uji normalitas dan uji linieritas regresi. Setelah itu dilakukan uji analisis data dengan menggunakan perhitungan uji hipotesis yang mencangkup uji koefisien korelasi, uji - t, uji regresi ganda dan uji koefisien determinasi.

HASIL DAN PEMBAHASAN PENELITIAN

1. Kepuasan Siswa Tentang Kinerja Guru Profesional

Tabel 1. Distribusi Kepuasan Siswa Tentang Kinerja Guru Profesional

\begin{tabular}{cccc}
\hline No. & $\begin{array}{c}\text { Kelas } \\
\text { Interval }\end{array}$ & $\begin{array}{c}\text { Frek. } \\
\text { Absolut }\end{array}$ & $\begin{array}{c}\text { Frek. } \\
\text { Relatif }\end{array}$ \\
\hline 1 & $47.5-50.5$ & 2 & $5.00 \%$ \\
2 & $50.5-53.5$ & 2 & $5.00 \%$ \\
3 & $53.5-56.5$ & 5 & $12.50 \%$ \\
4 & $56.5-59.5$ & 11 & $27.50 \%$ \\
5 & $59.5-62.5$ & 11 & $27.50 \%$ \\
6 & $62.5-65.5$ & 7 & $17.50 \%$ \\
7 & $65.5-68.5$ & 2 & $5.00 \%$ \\
& TOTAL & 40 & $100.00 \%$ \\
\hline
\end{tabular}

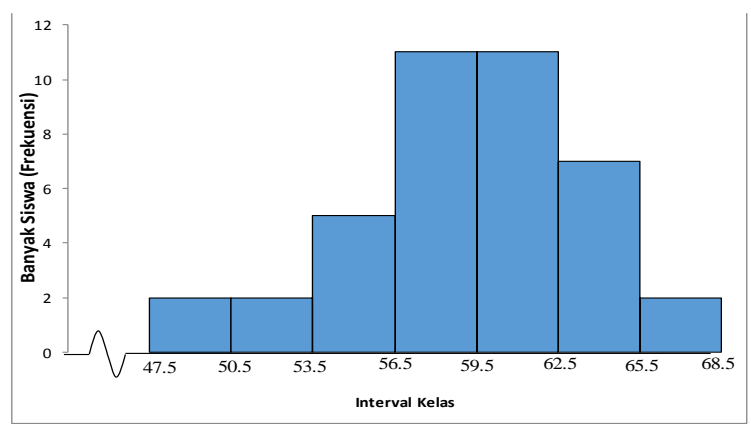

Gambar 1. Histogram Distribusi Frekuensi Kepuasan Siswa terhadap Kinerja Guru Profesional

Skor rata-rata variabel kepuasan siswa tentang kinerja guru profesional sebesar 58,53 jika dimasukkan dalam tabel kriteria penilaian ideal maka kepuasan siswa tentang kinerja guru profesional memiliki kategori 
kualitas sangat baik dengan persentase $86,07 \%$

2. Kinerja Guru Profesional

Tabel 2. Distribusi Frekuensi Kinerja Guru

Profesional Pekerjaan Dasar Elektromekanik

\begin{tabular}{cccc} 
No & $\begin{array}{c}\text { Kelas } \\
\text { Interval }\end{array}$ & $\begin{array}{c}\text { Frek. } \\
\text { Absolut }\end{array}$ & $\begin{array}{c}\text { Frek. } \\
\text { Relatif }\end{array}$ \\
\hline 1 & $46.5-49.5$ & 2 & $5.00 \%$ \\
2 & $49.5-52.5$ & 2 & $5.00 \%$ \\
3 & $52.5-55.5$ & 12 & $30.00 \%$ \\
4 & $55.5-58.5$ & 12 & $30.00 \%$ \\
5 & $58.5-61.5$ & 10 & $25.00 \%$ \\
6 & $61.5-64.5$ & 2 & $5.00 \%$ \\
& TOTAL & 40 & $100.00 \%$ \\
\hline
\end{tabular}

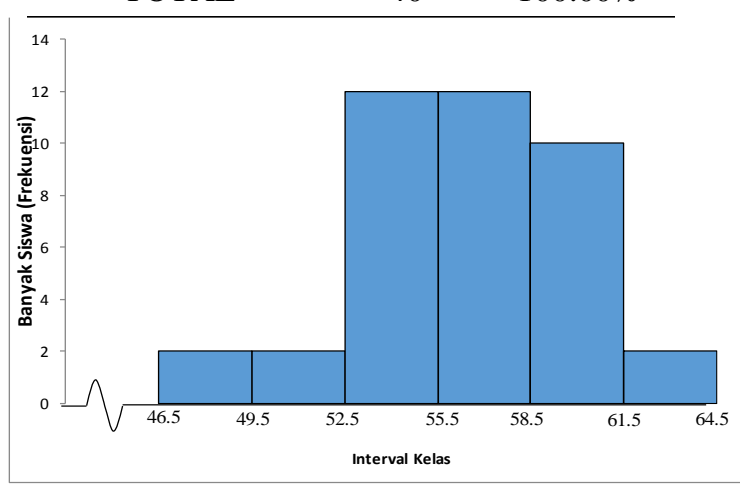

Gambar 2. Histogram Distribusi Frekuensi Kinerja Guru Profesional

3. Hasil Belajar

Tabel 3. Distribusi Frekuensi Hasil Belajar Pekerjaan Dasar Elektromekanik

\begin{tabular}{cccc}
\hline No. & $\begin{array}{c}\text { Kelas } \\
\text { Interval }\end{array}$ & $\begin{array}{c}\text { Frek. } \\
\text { Absolut }\end{array}$ & $\begin{array}{c}\text { Frek. } \\
\text { Relatif }\end{array}$ \\
\hline 1 & $75.5-78.5$ & 4 & $10.00 \%$ \\
2 & $78.5-81.5$ & 4 & $10.00 \%$ \\
3 & $81.5-84.5$ & 13 & $32.50 \%$ \\
4 & $84.5-87.5$ & 10 & $25.00 \%$ \\
5 & $87.5-90.5$ & 6 & $15.00 \%$ \\
6 & $90.5-93.5$ & 3 & $7.50 \%$ \\
& TOTAL & 40 & $100.00 \%$
\end{tabular}

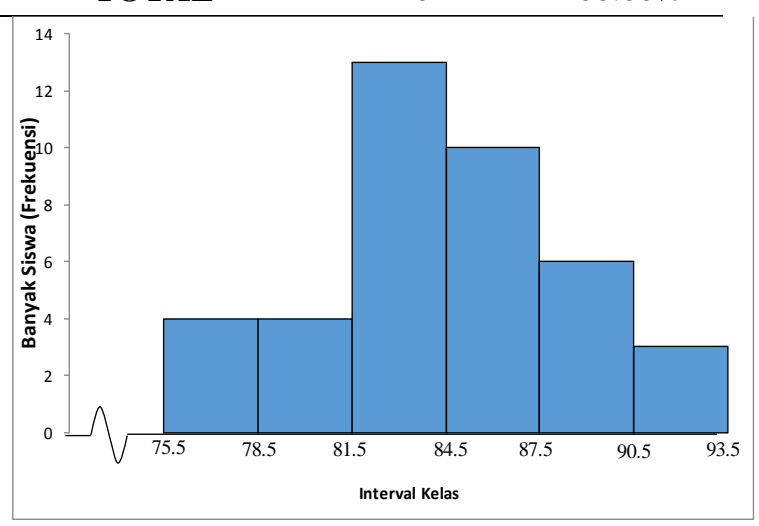

Gambar 3. Histogram Distribusi Frekuensi Hasil Belajar
Uji Normalitas

Tabel 4. Hasil Uji Normalitas Data

\begin{tabular}{ccccc}
\hline Variabel & $\mathbf{L}_{\text {hitung }}$ & $\mathbf{L}_{\text {tabel }}$ & Keputusan & Kesimpulan \\
$\mathbf{X}_{\mathbf{1}}$ & 0,08 & 0,14 & Terima Ho & Normal \\
$\mathbf{X 2}$ & 0,08 & 0,14 & Terima Ho & Normal \\
$\mathbf{Y}$ & 0,084 & 0,14 & Terima Ho & Normal \\
\hline
\end{tabular}

\section{Uji Keberartian dan Uji Linieritas Regresi}

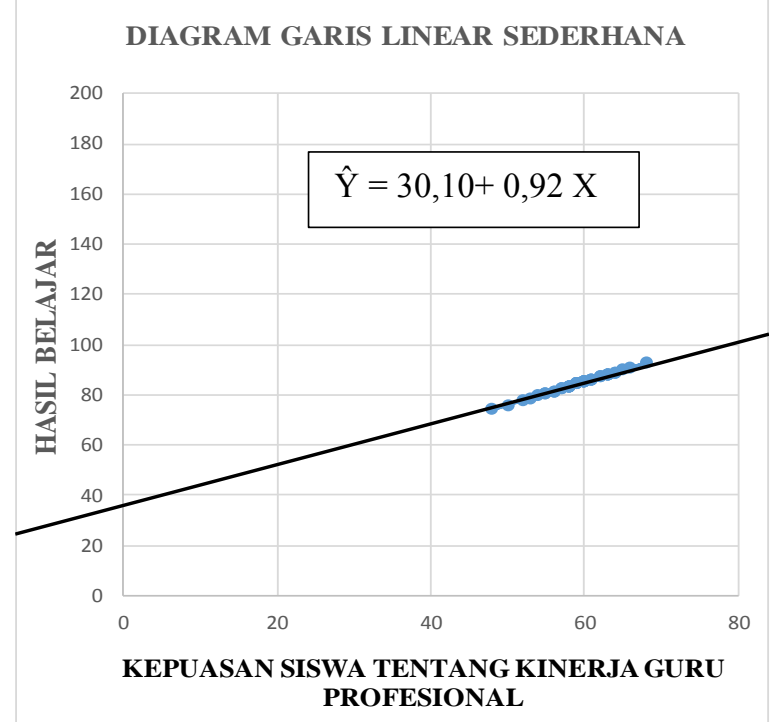

Gambar 4. Grafik Persamaan Regresi $X_{1}$ terhadap $Y$

Grafik di atas menunjukkan persamaan regresi dimana setiap kenaikan satu skor kepuasan siswa tentang kinerja guru profesional akan mengakibatkan kenaikan skor hasil belajar sebesar 0,92 pada konstanta 30,10.

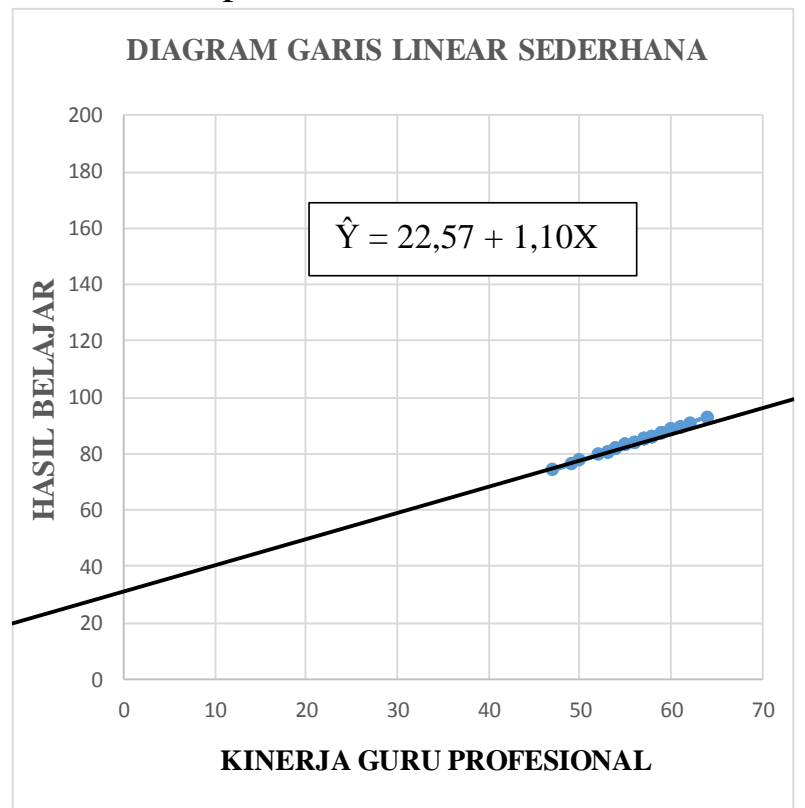

Gambar 5. Grafik Persamaan Regresi $X_{2}$ terhadap $Y$ 
Grafik di atas menunjukkan persamaan regresi dimana setiap kenaikan satu skor kinerja guru profesional akan mengakibatkan kenaikan skor hasil belajar sebesar 1,10 pada konstanta 22,57 .

Dari perhitungan persamaan regresi ganda $\left(\mathrm{X}_{1}\right.$ dan $\mathrm{X}_{2}$ terhadap $\mathrm{Y}$ ) dapat diketahui nilai a (konstanta) sebesar 23,53343734, nilai $b_{1}$ (koefisien regresi variabel $\mathrm{X}_{1}$ kepuasan siswa tentang kinerja guru profesional) sebesar 0,263422282 dan nilai $b_{2}$ (koefisien regresi variabel $\mathrm{X}_{2}$ kinerja guru profesional) sebesar

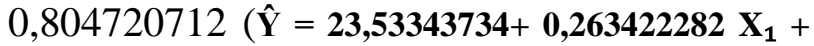
0,804720712 $\mathrm{X}_{2}$ )

Sehingga dapat disimpulkan bahwa hasil belajar siswa akan meningkat apabila kepuasan siswa tentang kinerja guru profesional dan kinerja guru profesional naik

\section{Uji Hipotesis}

Tabel 5. Hipotesis Pertama (Korelasi $\mathrm{X}_{1}$ dan $\mathrm{Y}$ )

\begin{tabular}{cccc}
\hline $\mathbf{R x y}$ & $\mathbf{R}^{\mathbf{2}}$ & $\mathbf{t}_{\text {hitung }}$ & $\mathbf{t}_{\text {tabel }}$ \\
\hline $\mathbf{0 , 9 2}$ & $84,73 \%$ & 14,52 & 2,02
\end{tabular}

Diperoleh nilai korelasi $\left(r_{x y}\right)$ sebesar 0,920 ; sedangkan $r_{\text {tabel }}$ pada taraf signifikasi 0,05 dan $n$ $=40$ adalah 0,312 ; karena $r_{\text {hitung lebih besar dari }}$ pada $r_{\text {tabel }}$ atau $0,920>0,312$. Dengan demikian dalam penelitian ini terdapat hubungan yang positif antara variabel X1 dan $\mathrm{Y}$. Hasil perhitungan $t_{\text {hitung }}$ sebesar $=14,52$ dan $t_{\text {tabel }}$ sebesar 2,02, artinya terdapat hubungan yang signifikan antara variabel X1 dan Y . Dan nilai koefisien determinasi antara kedua variabel adalah $84,73 \%$. Hal ini memiliki pengertian bahwa kontribusi antara kepuasan siswa tentang kinerja guru profesional dengan hasil siswa sebesar $84,73 \%$

Tabel 6. Hipotesis Kedua (Korelasi X2 dan Y)

\begin{tabular}{llll}
\hline $\mathbf{R x y}$ & $\mathbf{R}^{\mathbf{2}}$ & $\mathbf{t}_{\text {hitung }}$ & $\mathbf{t}_{\text {tabel }}$ \\
$\mathbf{0 , 9 4 0}$ & $88,44 \%$ & 17,05 & 2,02
\end{tabular}

Diperoleh nilai korelasi $\left(\mathrm{r}_{\mathrm{xy}}\right)$ sebesar 0,940; sedangkan $r_{\text {tabel }}$ pada taraf signifikasi 0,05 dan $n$ $=40$ adalah 0,312; karena $r_{\text {hitung }}$ lebih besar dari pada $r_{\text {tabel }}$ atau $0,940>0,312$. Dengan demikian dalam penelitian ini terdapat hubungan yang positif antara variabel X2 dan Y . Hasil perhitungan $t_{\text {hitung }}$ sebesar $=17,05$ dan $t_{\text {tabel }}$ sebesar 2,02, artinya terdapat hubungan yang signifikan antara variabel X2 dan Y . Dan nilai koefisien determinasi antara kedua variabel adalah 88,44\%. Hal ini memiliki pengertian bahwa kontribusi antara kinerja guru profesional dengan hasil siswa sebesar 88,44.

Tabel 7. Hipotesis Kedua (Korelasi X1 dan X2 dengan

\begin{tabular}{cc}
\multicolumn{2}{c}{$\mathrm{Y})$} \\
\hline $\mathbf{R x y}$ & $\mathbf{R}^{\mathbf{2}}$ \\
\hline $\mathbf{0 , 7 2 2}$ & 0,5215 \\
\hline
\end{tabular}

Diperoleh nilai korelasi ganda $\left(\mathrm{R}_{\mathrm{xy}}\right)$ sebesar 0,720; sehingga apabila dimasukkan ke dalam tabel interpretasi koefisien korelasi tergolong kuat. Dengan demikian dalam penelitian ini terdapat hubungan yang kuat antara variabel X1 $\mathrm{X} 2$ dan $\mathrm{Y}$

\section{KESIMPULAN DAN SARAN Kesimpulan}

1. Terdapat hubungan yang positif dan signifikan antara kepuasan siswa tentang kinerja guru profesional dengan hasil belajar siswa mata pelajaran pekerjaan dasar elektromekanik

2. Terdapat hubungan yang positif dan signifikan antara kinerja guru profesional dengan hasil belajar siswa mata pelajaran pekerjaan dasar elektromekanik

3. Secara bersama-sama terdapat hubungan yang positif dan signifikan antara kepuasan siswa tentang kinerja guru profesional dan kinerja guru profesional dengan hasil belajar siswa mata pelajaran pekerjaan dasar elektromekanik

\section{Saran}

Siswa diharapkan dapat memperbaiki cara belajarnya dengan berusaha belajar secara teratur atas inisiatif sendiri tanpa paksaan atau perintah orang lain, misalnya membuat jadwal belajar dan dilaksanakan dengan sebaikbaiknya. Hal ini dapat mengurangi kemungkinan mendapat nilai rendah pada saat ulangan, mengerjakan pekerjaan rumah ataupun pada saat latihan di sekolah.

Sementara itu, guru diharapkan mampu memperhatikan siswa secara keseluruhan dan mendampingi siswa di kelas selama mata pelajaran agar siswa yang tidak memahami materi dapat bertanya dan tidak ketinggalan pelajaran. Selain itu, siswa jadi lebih fokus dalam belajar di kelas. 


\section{DAFTAR PUSTAKA}

Ali, M \& Asrori, M. (2004) Psikologi Remaja : Perkembangan Peserta Didik. Jakarta : PT. Bumi Aksara

Alma, Buchari., Mulyadi, Hari., Razati, Girang., Nuryati, Lena. (2009). Guru Profesional. Bandung : Alfabeta

Arifin, Zainal. (2009). Evaluasi Pembelajaran: Prinsip, Teknik, Prosedur. Bandung : PT Remaja Rosdakarya.

Aritonang, Keke T. (2005). Kompensasi Kerja, Disiplin Kerja Guru dan Kinerja Guru SMP Kristen BPK PENABUR Jakarta. Jurnal Pendidikan Penabur $4: 5$

Aziz, Amka Abdul. (2012). Guru Profesional Berkarakter (Melahirkan Murid Unggul Menjawab Tantangan Masa Depan). Jakarta : Cempaka Putih

Barnawi \& Arifin, Mohammad. (2012). Instrumen Pembinaan Peningkatan, \& Penilaian Kinerja Guru Profesional. Jogjakarta : Ar-Ruzz Media

Daryanto. (2012). Evaluasi Pendidikan. Jakarta : Rineka Cipta

Departemen Pendidikan Nasional. (2003). Undang-Undang Nomor 20 Tahun 2003, Tentang Sistem Pendidikan Nasional. Jakarta: Depdiknas.

Departemen Pendidikan Nasional. (2005). Undang-Undang Nomor 14 Tahun 2005, Tentang Guru dan Dosen. Jakarta: Depdiknas.

Direktorat Tenaga Kependidikan Direktorat Jenderal. (2008) Peningkatan Mutu Pendidik dan Tenaga Kependidikan. Jakarta : Depdiknas

Djamarah, Syaiful Bahri \& Zain, Aswan. (2010). Strategi Belajar Mengajar. Jakarta : Rineka Cipta

Firdausi, Arif \& Barnawi. (2011). Profil Guru SMK Profesional. Jogjakarta : Ar-Ruzz Media

Jihad, Asep \& Haris, Abdul. (2012). Evaluasi Pembelajaran. Yogyakarta : Multi Pressindo

Purwanto. (2009). Evaluasi Hasil Belajar. Ed ke-1. Yogyakarta : Pustaka Pelajar

Riswandi. (2013). Psikologi Komunikasi. Yogyakarta : Graha Ilmu.

Riyandi, Yedi. (2014). Pengaruh Pemasaran Jasa Pendidikan Dan Kualitas Layanan
Akademik Terhadap Kepuasan Siswa Pada Sekolah Menengah Kejuruan Swasta Rumpun Otomotif Di Kecamatan Majalaya Kabupaten Bandung. Jurnal Pendidikan dan Pembelajaran. 20-21.

Rusdiana \& Heryati, Yeti. (2015). Pendidikan Profesi Keguruan Menjadi Guru Inspiratif dan Inovatif. Bandung : CV Pustaka Setia.

Soeprijanto. (2010). Pengukuran Kinerja Guru Praktik Kejuruan Konsep dan Teknik Pengembangan Instrumen. Jakarta : CV. Tursina

Sopiatin, Popi. (2010). Manajemen Belajar Berbasis Kepuasan Siswa. Bogor : Ghalih Indonesia

Sudjana, Nana. (2011). Penilaian Hasil Proses Belajar Mengajar. Bandung : PT Remaja Rosdakarya

Supardi. (2013). Kinerja Guru. Jakarta : PT Rajagrafindo Persada

Supranto, J. (2011). Pengukuran Tingkat Kepuasan Pelanggan Untuk Menaikkan Pangsa Pasar. Jakarta : Rineka Cipta

Suprihatiningrum, Jamil. (2013). Guru Profesional : Pedoman Kinerja, Kualifikasi \& Kompetensi Guru. Jogjakarta : Ar-Ruzz Media

Suyanto \& Jihad, Asep. (2013). Menjadi Guru Profesional Strategi

Meningkatkan Kualifikasi dan Kualitas Guru di Era Global. Jakarta : Erlangga

Suyatno., Sumedi, Pudjo., \& Riadi, Sugeng. (2009). Pengembangan Profesionalisme Guru 70 Tahun Abdul Malik Fadjar. Jakarta : Uhamka Press

Usman, Uzer. (2000). Menjadi Guru Profesional. Bandung : PT Remaja Rosdakarya

Wahab, Rohmalina. (2005). Psikologi Belajar. Jakarta : Raja Grafindo Persada

Yamin, Martinis \& Maisah. (2010). Standarisasi Kinerja Guru. Gaung Persada Jakarta : (GP press)

Zamroni, et al. (2009). Pengembangan Profesionalisme Guru 70 Tahun Abdul Malik Fadjar. Jakarta : Uhamka Press 